\title{
Improvement of fertility in post-partum beef cows by treatment with PMSG and progestagen
}

\author{
P. Mulvehill and J. M. Sreenan
}

The Agricultural Institute, Belclare, Tuam, Galway, Ireland

Many studies have shown that suckling beef cows have an extended anoestrous period after parturition (Wiltbank \& Cook, 1958; Foote \& Hunter, 1964; Chupin, Pelot, Alonso de Miguel \& Thimonier, 1976). The interval from parturition to first oestrus has been shown to be prolonged by lowenergy intake before or after parturition (Wiltbank, 1970) and also by suckling (Oxenreider 1968; Graves, Lauderdale, Hauser \& Casida, 1968; Wiltbank, 1970). Fertility following artificial insemination of nursing beef cows is lower than in non-nursing cows and in the former the fertility level increases with the interval from parturition (Graves et al., 1968). The use of exogenous steroids to induce oestrus in suckling cows has generally resulted in a decrease of the post-partum interval to oestrus but fertility levels have been low (Ulberg \& Lindley, 1960; Foote, Weeth \& Hunter, 1960; Foote \& Hunter, 1964; Smith \& Vincent, 1972). In cyclic animals, normal fertility has been obtained after administration of progestagen for oestrous cycle control (Wiltbank \& Kasson, 1968; Wishart \& Young, 1974; Roche, 1974; Sreenan \& Mulvehill, 1975). Using progestagens, Sreenan \& Mulvehill (1974) reported a calving rate of $48 \%$ in suckling beef cows following a fixed-time insemination. Stimulation of follicular growth following the use of PMSG has been reported to result in a higher oestrous response and improved degree of synchronization in heifers when administered in combination with a short-term oestrous synchronization treatment (Thimonier, Pelot \& Chupin, 1976).

The present work was carried out to determine the effect of treatment with exogenous gonadotrophin (PMSG) and progestagen on calving rate in suckling beef cows.

Multiparous suckling beef cows of the Hereford and Aberdeen Angus breeds were used. The date of calving before treatment was available for 89 of the cows. The 262 animals were treated on 22 farms between June and September 1975 as follows. Group 1. Progesterone (3.0 g)-impregnated intravaginal sponges were inserted into 142 cows for 9 days. On the day of insertion an i.m. injection of $250 \mathrm{mg}$ progesterone $+7.5 \mathrm{mg}$ oestradiol benzoate was given. Group 2. Cronolone (0.2 g SC-9880; G. D. Searle \& Co.)-impregnated intravaginal sponges were inserted into 120 cows for 9 days and an i.m. injection of $20 \mathrm{mg}$ Cronolone $+7.5 \mathrm{mg}$ oestradiol benzoate was given on the day of sponge insertion. Approximately half of the cows in each group received 750 i.u. PMSG (Folligon: Intervet) i.m. at the time of sponge removal. All treatments were represented on each farm and the animals were randomly allocated to the treatments. All animals were artificially inseminated (with frozenthawed semen) on a fixed-time basis at 48 and $72 \mathrm{~h}$ after sponge removal and without reference to the occurrence of oestrus. On each farm, all inseminations were carried out by the same technician.

In agreement with previous findings (Sreenan, 1975; Sreenan \& Mulvehill, 1975), sponge retention rates were $90 \%$ and $94 \%$ for progesterone and Cronolone sponges respectively, and fertility data, based on the calving rate from the fixed time inseminations, are presented for those cows retaining sponges.

Table 1. Calving rate $(\%)$ after the administration of PMSG in conjunction with a 9-day progestagen treatment for inducing oestrus and ovulation in post-partum beef cows

\begin{tabular}{lccccc}
\hline & \multicolumn{2}{c}{ Progesterone } & & \multicolumn{2}{c}{ Cronolone } \\
\cline { 2 - 3 } \cline { 5 - 6 } & -PMSG +PMSG & & -PMSG +PMSG \\
\hline No. of cows & 65 & 62 & & 54 & 59 \\
Calving rate (\%) & 57 & 71 & & 48 & 73 \\
No. of twin births & - & 2 & & - & 11 \\
\hline
\end{tabular}


The fertility levels are shown in Table 1 . Calving rates were slightly higher $(9 \%)$ in the progesterone-treated animals, but this difference was not significant. The administration of PMSG, however, significantly increased the calving rate in both groups separately (progesterone- $\chi^{2}=2.71 ; P<0.10$; Cronolone $\left.-\chi^{2}=7.24 ; P<0.01\right)$ and together (72\% compared with $\left.52.5 \%: \chi^{2}=9.20 ; P<0.05\right)$. Administration of PMSG also resulted in an overall twin-birth rate of $15 \%$ with most of these $(84.6 \%)$ occurring in the Cronolone + PMSG group.

In the cows for which the parturition to treatment intervals were known, the calving rates were $33 \%(\mathrm{~N}=9)$ and $58 \%(\mathrm{~N}=28)$ for animals treated with progestagen only before and after 60 days post partum respectively, and $72 \cdot 7 \%(\mathrm{~N}=11)$ and $73 \%(\mathrm{~N}=41)$ when $\mathrm{PMSG}$ was also given. Twin births occurred only after the progestagen + PMSG treatment, one set before 60 days and 8 after 60 days.

This high incidence of twin births among cows treated after 60 days post partum suggests that the endocrinological state of these animals is similar to that of cyclic cows and that PMSG given at this time results in an increased ovulation rate by augmenting the endogenous FSH concentrations. A reduced secretion of gonadotrophins from the beginning until the 8th month of pregnancy in the cow has been reported by Nalbandov \& Casida (1940) while a slight increase has been recorded in the last month (Labhsetwar, Collins, Tyler \& Casida, 1964). After parturition there is a decline in pituitary levels of FSH during the first 3 weeks post partum (Labhsetwar et al., 1964; Saiduddin, Riesen, Tyler \& Casida, 1968). Recent work by Chupin et al. (1976) has shown that ovarian activity, based on plasma progesterone levels, is resumed in less than $20 \%$ of nursing Charolais cows and in only $31 \%$ of nursing Salers cows by 60 days post partum. Graves et al. (1968) showed that a higher proportion of silent ovulations $(70.6 \%)$ occurred in suckling beef cows compared with non-suckling cows $(42.4 \%)$ in the post-partum period and that suckling also delayed the interval to first oestrus by 35-54 days.

The present results for suckling beef cows suggest that the gonadotrophin administration in conjunction with a short-term progestagen treatment is an effective method of inducing ovulation in these animals.

We thank Mr D. F. Wishart, G. D. Searle \& Co. Ltd, for the SC-9880 (Cronolone), and Mr A. McDonagh and Mr F. McGee for technical assistance. This work was supported by the Commission of the European Communities.

\section{References}

Chupin, D., Pelot, J., Alonso de Miguel, M. \& Thimonier, J. (1976) Progesterone assay for study of ovarian activity during post partum anoestrus in the cow. Proc. 8th Int. Congr. Anim. Reprod. \& A.I., Cracow 1, 54.

Foote, W.D. \& Hunter, J.E. (1964) Postpartum intervals of beef cows treated with progesterone and oestrogen. J. Anim. Sci. 23, 517-520.

Foote, W.D., Weeth, H.J. \& HuNTER, J.E. (1960) Effects of ovarian hormones on post partum reproductive activity in beef cows. J. Anim. Sci. 19, 1321.

Grayes, W.E., Lauderdale, J.W., Hauser, E.R. \& CASIDA, L.E. (1968) Relation of postpartum interval to pituitary gonadotropins, ovarian follicular development and fertility in beef cows (effect of suckling and interval to breeding). Res. Bull. Agric. Exp. Stn Univ. Wis. 270, 23-26.

Labhsetwar, A.P., Collins, W.E., Tyler, W.J. \& CASIDA, L.E. (1964) Some pituitary-ovarian relationships in the periparturient cow. J. Reprod. Fert. 8, 85-90.

Nalbandov, A. \& CASIdA, L.E. (1940) Gonadotropic action of pituitaries from pregnant cows. Endocrinology 27, 559-566.
OXENREIDER, S.L. (1968) Effect of suckling and ovarian function on postpartum reproductive activity in beef cows. Am. J. vet. Res. 29, 2099-2102.

RocHE, J.F. (1974) Effect of short-term progesterone treatment on oestrous response and fertility in heifers. J. Reprod. Fert. 40, 433-440

Saiduddin, S., Riesen, J.W., Tyler, W.J. \& Casida, L.E. (1968) Relation of postpartum interval to pituitary gonadotrophins, ovarian follicular development and fertility in dairy cows (effect of suckling, feeding level, breeding management and genetic level of milk production). Res. Bull. Agric. Exp. Stn Univ. Wis. 270, 15-22.

SMITH, L.E. \& VINCENT, C.K. (1972) Effects of early weaning and exogenous hormone treatment on bovine post partum reproduction. J. Anim. Sci. 35, 1128-1232.

SReEnAN, J.M. (1975) Effect of long- and short-term intravaginal progestagen treatments on synchronization of oestrus and fertility in heifers. $J$. Reprod. Fert. 45, 479-485.

Sreenan, J.M. \& Mulvehill, P. (1974) Short-term (9-10 day) progestagen treatments for oestrous cycle 
control in cattle. Anim. Prod. Res. Report, Agricultural Institute, Dublin, p. 199.

Sreenan, J.M. \& Mulvehll, P. (1975) The application of long- and short-term progestagen treatments for oestrous cycle control in heifers. J. Reprod. Fert. 45, 367-369.

Thimonier, J., Pelot, J. \& Chupin, D. (1976) Synchronization of oestrus in the cow with progestagens and prostaglandins. Proc. E.E.C. Seminar Egg Transfer in Cattle, Cambridge pp. 279-288.

UlberG, L.C. \& LiNDley, C.E. (1960) Use of progesterone and estrogen in the control of reproductive activities in beef cattle. J. Anim. Sci. 19, 1132-1142.
WILTBank, J.N. (1970) Research needs in beef cattle reproduction. J. Anim. Sci. 31, 755-762

Wultbank, J.N. \& Cook, A.C. (1958) The comparative reproduction performance of nursed and milked cows. J. Anim. Sci. 17, 640-648.

Wiltbank, J.N. \& Kasson, C.W. (1968) Synchronization of oestrus in cattle with an oral progestational agent and an injection of an estrogen. J. Anim. Sci. 27, 113-116.

WisharT, D.F. \& Young, I.M. (1974) Artificial insemination of cattle at a predetermined time following treatment with a potent progestin (SC-21009). Vet. Rec. 95, 503-508.

Received 19 October 1976 